\section{Molecular markers in the diagnosis of thyroid nodules}

\author{
Marcadores moleculares no diagnóstico de nódulos tireoidianos
}

Laura S. Ward', Richard T. Kloos²

\section{SUMMARY}

An indeterminate thyroid nodule cytology result occurs about every sixth fine-needle aspiration. These indeterminate nodules harbor a $24 \%$ risk of malignancy (ROM); too high to ignore, but driving surgery where most nodules are benign. Molecular diagnostics have emerged to ideally avoid surgery when appropriate, and to trigger the correct therapeutic surgery when indicated, as opposed to an incomplete diagnostic surgery. No current molecular test offers both high sensitivity and high specificity. A molecular diagnostic test with high sensitivity (e.g. Afirma Gene Expression Classifier sensitivity 90\%) offers a high Negative Predictive Value when the ROM is relatively low, such as $<30 \%$. Only such tests can "rule-out" cancer. In this setting, a molecularly benign result suggests the same ROM as that of operated cytologically benign nodules ( $6 \%)$. Thus, clinical observation can replace diagnostic surgery; increasing quality of life and decreasing medical costs. However, its low specificity cannot "rule-in" cancer as a suspicious result has a Positive Predictive Value (PPV) of $\sim 40 \%$, perhaps too low to routinely reflex to definitive cancer surgery. Conversely, high specificity tests (BRAF, RAS, PPAR/PAX-8, RET/PTC, PTEN) offer high PPV results, and only these tests can "rule-in" cancer. Here a positive molecular result warrants definitive therapeutic surgery. However, their low sensitivity cannot "rule-out" cancer and a negative molecular result cannot dissuade diagnostic surgery; limiting their cost-effectiveness. Whether or not there is a useful and cost-effective role to sequentially combine these approaches, or to modify existing approaches, is under investigation. Arq Bras Endocrinol Metab. 2013;57(2):89-97

\section{Keywords}

Biopsy, fine-needle; DNA mutational analysis; gene expression; genomics; molecular diagnostic techniques

\section{SUMÁRIO}

Resultados indeterminados na citologia de um nódulo tireoidiano ocorrem em cerca de um a cada seis punções aspirativas por agulha fina. Esses nódulos indeterminados apresentam risco de malignidade (RM) de cerca de $24 \%$, um valor alto demais para ser ignorado e que leva à cirurgia em casos em que a maioria dos nódulos é benigna. $O$ diagnóstico molecular é uma forma ideal de se evitar a cirurgia quando apropriado e de se levar ao correto procedimento cirúrgico terapêutico quando indicado, em oposição à cirurgia diagnóstica incompleta. Atualmente, não existem testes moleculares com alta sensibilidade e especificidade. Um teste molecular de alta sensibilidade (por exemplo, a sensibilidade do teste Afirma Gene Expression Classifier é de 90\%) tem um alto Valor Preditivo Negativo quando o RM é relativamente baixo, por exemplo, $<30 \%$. Apenas esses testes podem "excluir" o câncer. Nesse contexto, um resultado molecular benigno sugere o mesmo RM de nódulos com resultado benigno na citologia e operados ( 6\%). Assim, a observação clínica pode substituir a cirurgia diagnóstica, aumentando a qualidade de vida e diminuindo os custos médicos. Entretanto, a baixa especificidade não pode "incluir" o câncer como um resultado suspeito quando esse resultado tem um Valor Preditivo Positivo (VPP) $40 \%$, que é talvez baixo demais para levar, rotineiramente, à cirurgia definitiva para o câncer. Por outro lado, testes com alta especificidade (BRAF, RAS, PPAR/PAX-8, RET/PTC, PTEN) têm alto VPP, e apenas esses testes podem "incluir" o câncer. Nesse caso, um resultado molecular positivo leva à recomendação de cirurgia terapêutica definitiva. Entretanto, sua baixa sensibilidade não pode "excluir" o câncer, e um resultado molecular negativo não pode dissuadir o médico de executar a cirurgia diagnóstica, limitando seu custo-benefício. Ainda se investiga se existe ou não um modo útil e com alto custo-benefício de se combinar essas abordagens sequencialmente, ou de se modificar as abordagens existentes. Arq Bras Endocrinol Metab. 2013;57(2):89-97

\section{Descritores}

Biópsia, agulha fina; análise de mutações no DNA; expressão gênica; estudo do genoma; técnicas de diagnóstico molecular

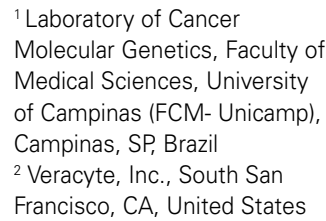

Correspondence to: Laura S. Ward

Laboratory of Cancer Molecular Genetics,

Faculty of Medical Sciences,

PO Box 6111

Rua Tessália Vieira de Camargo, 126

13083-887 - Campinas, SP, Brazil

ward@fcm.unicamp.br

Received on Jan/26/2013 Accepted on Feb/3/2013 


\section{INTRODUCTION}

$\mathrm{P}$ rior to the advent of thyroid nodule fine-needle aspiration (FNA) biopsy, these nodules were routinely referred for diagnostic surgery because of their $5 \%-15 \%$ risk of malignancy (ROM) (1). FNA decreased diagnostic thyroidectomies by one-half as most FNAs are conclusively diagnosed as benign cytologically (2). Still, 15\%-30\% of thyroid FNAs are cytologically indeterminate, i.e. not clearly benign nor malignant $(1,3)$. When cytologically indeterminate thyroid nodules undergo diagnostic surgery, three-quarters prove to be benign $(4,5)$. Therefore, a significant opportunity exists to improve the care of patients with cytologically indeterminate nodules using novel genomic diagnostic technology. Current opportunities include the accurate pre-operative identification of (i) benign nodules to safely avoid diagnostic surgery, (ii) malignant nodules to direct an optimal initial treatment (e.g. total thyroidectomy instead of a diagnostic hemithyroidectomy with a subsequent second surgery for completion thyroidectomy), and (iii) rare neoplasms requiring evaluations and/or treatments that differ from typical differentiated thyroid cancer (e.g. medullary thyroid cancer, metastases to the thyroid).

\section{Cost, morbidity, and risk of mortality from surgery}

The costs of diagnostic surgery include direct costs of the procedure (and its complications), indirect costs of time lost from work and responsibilities of daily living, and impaired quality of life (the fear of potentially having cancer and the anxiety of undergoing surgery, and the post-operative pain and suffering from surgery, and the potentially impaired quality of life from iatrogenic hypothyroidism with (6), or without (7), a normal serum TSH and its consequences).

Thyroid surgeries carry a perioperative mortality rate of $0.1 \%-0.2 \%$, with rates as high as $0.5 \%(8-10)$. Serious or permanent non-lethal complications of thyroidectomy include hypocalcemia, recurrent laryngeal nerve damage, re-bleeding and wound infection (11). These complications are more frequent than commonly appreciated, and are strongly related to surgeon experience (volume) and expertise. In Brazil, complications occurred in $34.7 \%$ of the thyroidectomies performed in a University Hospital, including hypoparathyroidism in $8.8 \%$ (12). Complication rates of thyroid surgeries in a US population-based study were found to be $10.1 \%$ for surgeons who did between one and nine cases per year, and $5.9 \%$ for surgeons who did more than one hundred cases per year (13). In fact, over $50 \%$ of thyroid surgeries in the US are performed by surgeons who do five or fewer cases per year (14), placing many patients at a higher risk of complications. In Spain, a study of surgeons performing less than 5 thyroid surgeries per year demonstrated hypocalcemia rates of $50 \%$ and $19 \%$ at 6 and 12 months, respectively (15). Figures in Brazil are likely similar.

\section{Current management of cytologically benign thyroid FNA biopsies}

The gold-standard to determine benign versus malignant status for all thyroid nodules, including those with benign FNAs, is surgical histology. Current ATA and AACE guidelines recommend close clinical and sonographic follow-up of cytologically benign nodules six to eighteen months following the FNA biopsy, despite an average ROM [1- negative predictive value (NPV)] for operated cytologically benign nodules of $6 \%-8 \%$ across multiple studies $(4,16-21)$ (Figure 1), and ranging as high as $33 \%$ (17). Thus, the average NPV, or accuracy of a benign diagnosis for thyroid FNA is $92 \%-94 \%$ $(4,17,18)$. The NPV of the Afirma Gene Expression Classifier (GEC) applied to cytologically indeterminate thyroid nodules (Bethesda categories III and IV) is therefore similar to that of a benign cytological diagnosis (Figure 2) (20). It follows that these two thyroid nodule scenarios should be treated similarly. Watchful waiting in lieu of diagnostic thyroidectomy is considered safe for cytologically benign thyroid nodules because thyroid cancer is relatively indolent, except for anaplastic thyroid cancer whose malignant nature is usually both clinically and cytologically obvious. Thus,

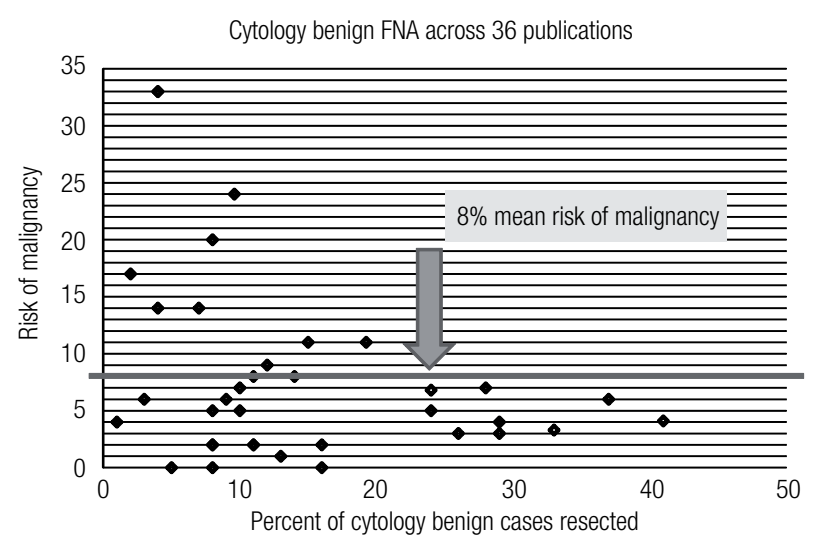

Figure 1. Risk of malignancy among cytologically benign thyroid FNAs across 36 publications (17). 
even when the benign cytological diagnosis is wrong, if the patient undergoes surgery within twelve months their five-year risk of mortality and local recurrence is unchanged (1). In fact, papillary thyroid carcinoma (PTC) of any size that is confined to the thyroid gland (no extraglandular extension or lymph node metastases at presentation) has a favorable outcome whether or not they are treated in the first year after diagnosis (22). Indeed, the indolent nature of PTC has prompted observational trials in microPTC (23).

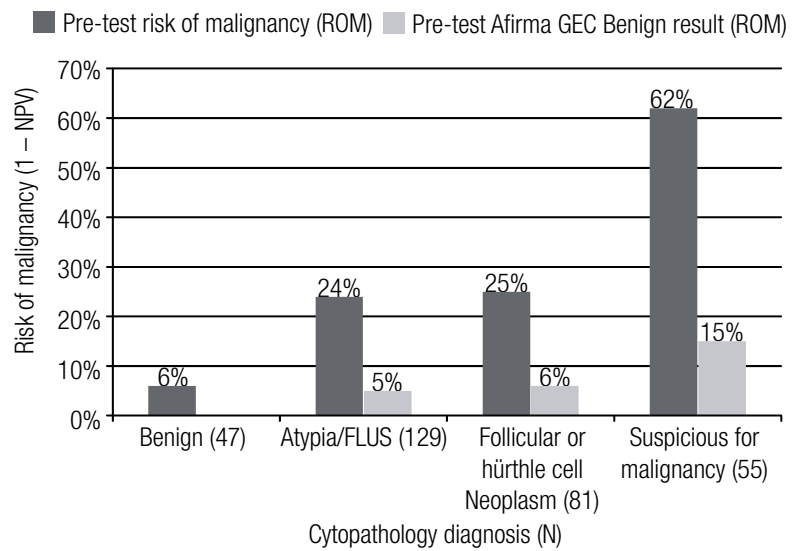

Figure 2. Afirma Gene Expression Classifier (GEC) reclassifies cytologically indeterminate thyroid nodules with a low risk of malignancy (ROM) to GEC Benign (20). ROM is 1-negative predictive value (NPV).

\section{Cytologically indeterminate FNAs are problematic, so can they be reclassified?}

Physicians recognize that indeterminate FNA results do not resolve the clinical question proposed: is the nodule benign or malignant? One solution would be to label fewer FNAs as cytologically indeterminate. Cytologically indeterminate samples comprise $10 \%-26 \%$ of all samples, averaging $17 \%$ (4). Some cytopathology experts claim that they can safely render indeterminate diagnoses much less often, but considering the potentially high number of false negative results (missed cancers) in operated cytologically benign nodules $(4,17,18)$, there may be significant risk with very low cytology indeterminate rates, assuming the rate is lowered by moving many of these samples to the benign cytology category (24).

Classification systems with one indeterminate cytology category have postulated that subdividing this category into subcategories at higher and lower risk could improve clinical care $(25,26)$. The Bethesda system created three indeterminate categories: atypia or follicu- lar lesion of undetermined significance (AUS/FLUS, category III), follicular and Hürthle cell neoplasm or suspicious for same (FN/SFN, category IV), and suspicious for malignancy (category V) (26). Unfortunately, it appears that this expansion created less reproducible categorization (27), and has not solved the problem.

The Bethesda system postulated that the FN/SFN category would require diagnostic surgery, while the ROM in the AUS/FLUS category would be significantly lower and best served by a repeat FNA that may resolve the majority of cases. Currently, this differential approach is being questioned. The literature strongly suggests that the ROM for AUS/FLUS lesions is significantly higher than postulated by the Bethesda Classification creators $(20,24,28-30)$. Additionally, some literature suggests that the ROM in AUS/FLUS may not be significantly lower than FN/SFN $(21,29)$. Bongiovanni and cols. reported a $22 \% \operatorname{ROM}(29)$, a finding consistent with a recent large multicenter prospective study where the ROM for AUS/FLUS was 24\% while the ROM for FN/SFN was $25 \%$ (20). Thus, if the ROM for AUS/FLUS lesions is higher than originally projected, or if the ROM is similar to that of the FN/ SFN category, then is it optimal to surgically resection FN/SFN nodules while repeating the FNA for AUS/ FLUS nodules (28)?

In addition, some studies $(28,31)$ [but not all $(30,32)$ ] suggest that the ROM in a benign FNA after an initial AUS/FLUS biopsy is of intermediate risk between the two categories (i.e. the second benign FNA cannot make the first AUS/FLUS FNA go away). These studies suggest that the remaining ROM in a follow-up benign FNA remains high enough that diagnostic surgery may not be avoidable.

\section{APPLICATION OF IMMUNOHISTOCHEMISTRY TO FNA CYTOLOGY}

A number of immunohistochemical approaches have been applied to indeterminate cytology specimens in an effort to reclassify these samples, including galectin-3, HBME-1, and CK19 $(33,34)$. This approach is best at identifying classic PTC, but sensitivity progressively declines when one encounters fvPTC, FTC, and less common malignant variants. Further, specificity is impaired as some immunohistochemical approaches are positive in benign tissues, including follicular adenomas, hyperplastic nodules, and normal thyroid tissue. Most importantly, blinded, prospective, large-scale, 
multicenter clinical trials investigating immunohistochemical markers are lacking (34). Thus, most cytopathologists view immunohistochemistry as having a very limited role in thyroid cytology (29).

\section{MicroRNA analyses}

MicroRNAs are small RNA sequences (19-25 nucleotides) that function to regulate the expression of genes. Amid mixed results, several studies have suggested that aberrant miR expression profiles may separate thyroid cancers from benign thyroid lesions and normal thyroid tissue (34-36). However, this approach has yet to be tested on indeterminate FNAs in a large, prospective, blinded, multicenter study $(34,35)$.

\section{DNA mutation/rearrangement testing}

Malignant thyroid nodules with indeterminate Bethesda categories III and IV cytology have a low incidence of BRAF mutation $(37,38)$. This is not unexpected as these thyroid nodule categories include malignant tumors that less commonly (or never) harbor BRAF mutations such as follicular thyroid cancer, Hürthle cell thyroid cancer, follicular variant PTC, and medullary thyroid cancer. However, the low incidence is also explained by the finding that BRAF mutated PTCs have cytological features that cytopathologists recognize and classify as suspicious for malignancy or malignant (Bethesda categories V and VI); cytological categories typically treated with total thyroidectomy regardless of BRAF status (37). Conversely, PTCs with indeterminate cytology are more often BRAF negative $(37,38)$.

A test that cannot detect cancer with very high sensitivity cannot successfully "rule out" cancer. DNA mutations such as BRAF, RAS, and RET/PTC and PAX8/ $P P A R G$ translocations have high positive predictive value (PPV) and when detected they predict ("rule in") the histological diagnosis of thyroid cancer. However, when they are absent, cancer cannot be "ruled out" because of the low sensitivity and NPV of these markers. A review of four studies combining all four mutation-markers into a single panel had $64 \%$ sensitivity, thus failing to identify $36 \%$ of thyroid cancers (39). The largest study of mutational markers was a retrospective analysis of prospectively collected samples where the mutational status was available to the clinicians, including the histopathologist (38). The mutational marker NPV for Bethesda categories IV and V were $86 \%$ and $72 \%$, respectively. Thus, malignancy could not be ade- quately excluded to avoid surgery. For Bethesda category III test sensitivity was $63 \%$, specificity $99 \%$, and NPV $94 \%$ with a $14 \%$ prevalence of malignancy. When applied to the $24 \%$ prevalence of malignancy seen in the large, multicenter (academic and community), prospective, and blinded study of Alexander and cols. (20) the resultant NPV declines to 89\% (Figure 3). High PPV tests with inadequate NPV performance can "rule in" cancer and perhaps alter the extent of surgery, but they cannot "rule out" cancer, so surgery cannot be avoided. Currently, the strongest argument for their use is where the decision has been made for surgery, but the extent of surgery may be determined by the test result $(38,40)$. Based on the potential ability to prevent completion thyroidectomies by performing an initial total thyroidectomy in patients with indeterminate cytology when a DNA mutation is present, Yip and cols. reported the possibility of cost savings by mutation panel testing in a decision-tree model (40). Still, no prospective study using patients has assessed the clinical utility of DNA mutation panels on thyroid surgery. The available clinical validity data are limited to retrospective analyses of methodologies from academic laboratories $(38,39)$, and no data are available to assess the analytical or clinical validity of commercially available DNA mutation panels. BRAF mutations are uncommon in Bethesda categories III and IV $(37,38)$, and RET/PTC and PAX8/PPARG translocations are rare in all cytologically indeterminate categories $(29,34,38)$. BRAF

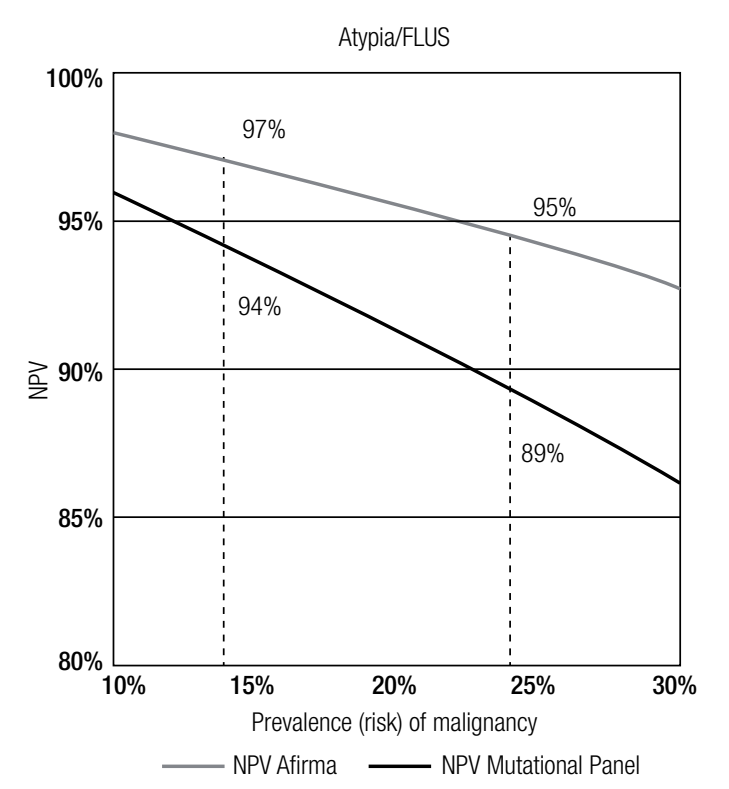

Figure 3. Negative predictive value (NPV) of Afirma (20) and a Mutational Panel (38) according to the prevalence of malignancy. 
mutations are more prevalent in Bethesda category $\mathrm{V}$ (38) where the $\sim 62 \% \operatorname{ROM}(4,20)$ is high enough that most of these patients are already treated with a total thyroidectomy. Kleiman and cols. reported that preoperative screening for $B R A F$ mutations was unlikely to alter patient management at their center (37).

\section{Veracyte Afirma Gene Expression Classifier (GEC)}

The Afirma GEC, based on the measurement of mRNA expression, was developed and clinically validated to identify pre-operatively histologically benign nodules amongst those with indeterminate cytology. By pre-operatively identifying these patients, clinical and sonographic follow-up may be recommended in lieu of diagnostic surgery, thus ending the diagnostic odyssey (Figure 4) $(41,42)$. The Afirma GEC analysis is indicated only for nodules with indeterminate cytology, and is not performed on cytologically benign, malignant or nondiagnostic (insufficient) FNA samples.

The Afirma GEC is provided by Veracyte's CLIA-certified clinical laboratory. The molecular classifier proceeds in a step-wise fashion, first applying 6 cassettes before applying the final benign versus malignant classifier. These cassettes differentiate specific rare neoplasm subtypes and act as filters that halt further sample processing if any cassette returns a "suspicious" result. This prevents some of the rare, nonfollicular cell-derived neoplasms from being scored by the main classifier. These cassettes classify samples representing (1) malignant melanoma, (2) renal cell carcinoma, (3) breast carcinoma, (4) parathyroid tissue, and (5) medullary thyroid carcinoma. A final cassette (6) was also trained

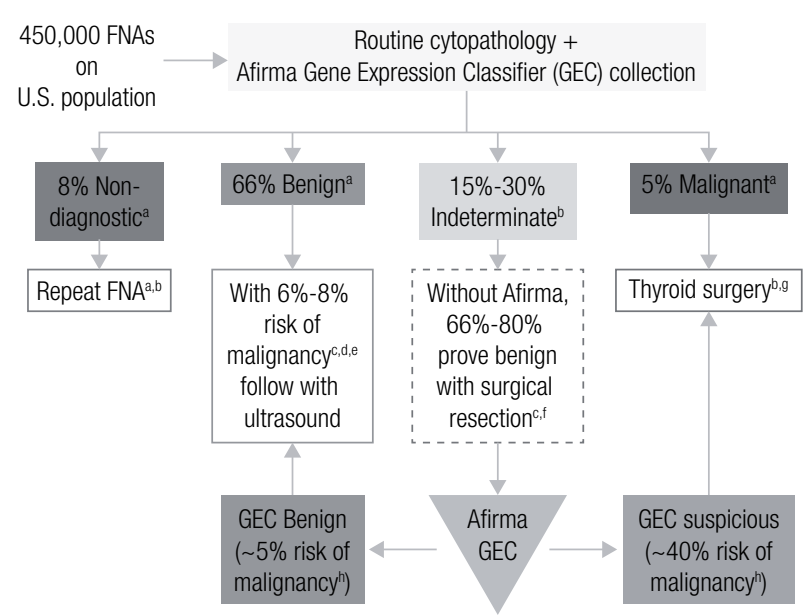

Figure 4. Implementing the Afirma gene expression classifier (GEC) into clinical practice. Indeterminate is Bethesda categories III and IV (26). Superscript references: a (60), b (1), c (4), d (18), e (17), f (5), g (42), h (20). using Hürthle cell adenomas and carcinomas. Failing to trigger one of these rare neoplasm cassettes, the GEC evaluates the expression of 142 genes that are used in a proprietary algorithm to classify indeterminate thyroid nodule FNAs as either "Benign" or "Suspicious".

\section{Analytical validity}

The GEC performance was evaluated in a series of forty-three individual reagent and analytical verification studies. Extensive reagent and analytical performance studies were conducted to evaluate the reliability and reproducibility of the GEC under a variety of experimental and clinical conditions, with robust and highly reproducible results (43). Interfering substances including human blood and genomic DNA were not found to interfere with extraction or amplification steps of the assay. Analytical sensitivity studies demonstrated tolerance to variations in RNA input across the range of 5 ng to $25 \mathrm{ng}$, as well as dilution of malignant FNA material down to $20 \%$ with FNA material from lymphocytic thyroiditis and nodule hyperplasia. Analytical sensitivity and specificity studies with blood (up to 83\%) and genomic DNA (30\%) demonstrated negligible assay interference, although false positive results could result from very bloody FNAs. FNA preservative solution maintained high quality and quantity of RNA material under various stressed time, temperature, and shipping conditions with no significant effect on GEC scores, or "Benign" versus "Suspicious" calls (100\% concordance). Based on these data, room-temperature storage at the clinical site and chilled-box shipping was verified for routine practice.

\section{Clinical validity}

A whole genome approach identified candidate genes, and support vector machine learning methods were used to develop the classifier algorithm. The initial publication included test validation on an independent sample set of cytologically indeterminate thyroid nodule FNAs with a prospective multicenter, double blind study design (44). The Afirma GEC achieved high sensitivity and NPV. After further optimization, the 142 gene classifier was validated in a second prospective multicenter validation study. The study included the largest ever prospectively collected set of thyroid FNA biopsies from 3,789 unique patients. Based on the expected $24 \%$ prevalence of malignancy in cytologically indeterminate samples in clinical practice, a 95\% NPV 
for the Afirma GEC was achieved on an independent sample set of 265 cytologically indeterminate nodules when the molecular results were compared to blinded gold standard histopathology diagnosis (20). Thus, the ROM for a thyroid nodule with Bethesda categories III and IV indeterminate cytology but an Afirma GEC Benign classifier result is about $5 \%$. This risk is comparable to the $6 \%-8 \%$ cancer risk for a thyroid nodule with a benign cytology diagnosis (Figures 1-4) (4,16-21). This suggests that GEC Benign cytologically indeterminate (Bethesda categories III and IV) nodules can be managed as would a cytologically benign nodule, as suggested by the NCCN Thyroid Carcinoma Guideline (42). Specificity is the percentage of truly benign nodules identified by the test. The GEC raised specificity from $0 \%$ for cytologically indeterminate categories to $52 \%$ when the GEC was Benign. This indicates that just over half of the benign nodules from Bethesda categories III and IV can be identified and removed from the surgical pool. For Bethesda category $\mathrm{V}$ nodules (suspicious for malignancy), the sensitivity and specificity performance of the GEC was comparable, but the high prevalence of malignancy in this category lowers the NPV to $85 \%$ (Figure 2). Thus, while the ROM is reduced from an initial $62 \%$ based on the cytological category to $15 \%$ when the GEC is benign, surgery may not be avoidable based on the residual ROM and therefore these nodules are not routinely reflexed to GEC testing. However, some physicians request the GEC to be performed in this cytological category to screen the sample with the rare neoplasm cassettes, and because they may alter the extent of surgery from a total thyroidectomy to a diagnostic hemithyroidectomy when the GEC is benign.

Optimally, physicians routinely collect the Afirma GEC with every FNA they perform, or have on-site rapid cytological assessment so that the GEC can be collected on every patient with indeterminate cytology during one patient visit (Figure 4). This avoids the inconvenience, delayed diagnosis, and costs associated with repeating the FNA when the first FNA comes back indeterminate. Additionally, it is well known that cytologically indeterminate nodules may not be categorized as indeterminate if they undergo a repeat FNA (28). At first blush, a repeat FNA would seem like a good idea to potentially re-stratify cytologically indeterminate patients as either cytologically benign or malignant. Unfortunately, this creates a conundrum for patients whose repeat FNA is cytologically benign as their ROM may not be fully reduced to the same risk as if their first FNA had been cyto- logically benign $(28,31)$. The conundrum is accentuated by the fact that the GEC is not indicated for cytologically benign material as this is not cost-effective due to the low PPV that results from the low prevalence of malignancy in this setting, and because the GEC specificity of 70\% for cytologically benign nodules will predictably result in a false-positive GEC Suspicious call in many cytology benign nodules (20). For these reasons, the GEC specimen must be collected at the same time as paired cytology, optimally collected during the first thyroid FNA. When GEC testing is desired in a patient for whom only cytology was previously collected, the cytology must be repeated along with the GEC collection.

\section{Rare neoplasms}

The cytological diagnosis of medullary thyroid cancer (MTC) is challenging. The tumor is uncommon and its cytological features overlap with those of other neoplasms. When the cytopathologist wrongly suspects MTC, these false positive diagnoses lower cytological specificity (45-48). More significant is that non-specific cytological features may wrongly suggest tumors other than MTC. These false negative diagnoses result in the failure to cytologically diagnose MTC, and lower cytological sensitivity for MTC (45,47-54). An abstract reporting 14 samples (from 13 patients) that positively expressed the MTC gene expression signature in the Afirma GEC rare neoplasm cassettes found that all 14 were confirmed as MTC on histopathology (55). Experience with a larger number of MTC cases is needed before stronger conclusions can be drawn about the test's specificity, although high specificity would fill an important clinical gap as the main drawback of serum calcitonin screening for MTC is its high false positive rate (56). However, of the 265 histologically confirmed specimens reported by Alexander and cols, none of the 263 non-MTC specimens triggered the MTC cassette, so early findings suggest high specificity (20). In the more than 5000 GEC samples processed as of December 1, 2012, all samples that have triggered the MTC cassette have been confirmed (or are pending confirmation) to be MTC, while Veracyte is unaware of a histologically confirmed MTC that failed to trigger the cassette (unpublished data). These findings suggest that the MTC rare neoplasm cassette has both high PPV and high NPV. A pre-operative diagnosis of MTC impacts the patient pre-operative evaluation, including evaluation for multiple endocrine neoplasia type 2 (MEN2), and the risk of concomitant pheochromocytoma and hyperparathyroidism. Additio- 
nally, surgical management is altered to include a minimum of total thyroidectomy and central neck dissection. Finally, pre-operative RET proto-oncogene status alters management of unintentionally devascularized parathyroid glands (57).

Experience with the other rare neoplasm cassettes is more limited, however, the renal cell carcinoma, breast carcinoma, and parathyroid tissue cassettes have all been triggered and surgical confirmation of these diagnoses have been confirmed in nearly all cases (unpublished data).

\section{Clinical utility and cost-effectiveness}

The impact of the Afirma GEC on the physician decision to refer to surgery when the FNA cytology is indeterminate but the Afirma GEC result is benign has been studied. Duick and cols. reported on the initial 2,040 consecutive indeterminate thyroid FNA biopsies collected in clinical practice through March 2012 (58). Fifty-two percent of these cytologically indeterminate samples were GEC benign. Fifty-one physicians (46 community-based, 5 academic) at 21 practice locations participated. Decisions were analyzed for 368 patients (395 nodules). Physicians adopted watchful waiting in lieu of diagnostic thyroid surgery $92.4 \%$ of the time when the Afirma GEC result reclassified the cytologically indeterminate nodule as benign. In contrast to the $74 \%$ historical rate of diagnostic surgery on cytologically indeterminate thyroid nodules (4), 7.6\% of those that were Afirma GEC benign proceeded to surgery, a dramatic $90 \%$ reduction in the decision to operate $(\mathrm{p}<$ 0.001 ) (58). The decision to operate was not statistically different from the $9 \%$ operative rate on patients with benign cytology diagnoses reported in a recent meta-review (4). Physicians who choose to proceed to surgery with an Afirma GEC benign result reported similar reasons to operate as those found for operated cytologically benign nodules (e.g. large nodule, compression, other suspicious nodule, rapid nodule growth) (58).

An independent study found no difference in missed cancers between the current care paradigm and the Afirma GEC in a Markov model employing 10,000 Monte Carlo simulations of the expected range of probabilities for different potential outcomes (59). They also modeled the cost effectiveness and impact on quality adjusted life years (QALYs) over a five year period for usual care versus utilization of the Afirma GEC in the United States. Compared to the traditional care paradigm, the Afirma GEC modestly improved quality of life while re- ducing direct healthcare costs by $\$ 4,653$ per five year episode of care (allowing $\$ 1,453$ in direct savings assuming the test cost $\$ 3,200)$ (59). This cost savings estimate was conservative because it projected a $14 \%$ rate of operation on GEC benign thyroid nodules (based on expert opinion), a rate almost twice the $7.6 \%$ rate subsequently reported in actual clinical practice (58). Using the actual rate of thyroidectomy when the GEC is benign, each test would have saved \$2,600 (58).

\section{CONCLUSION}

The introduction of thyroid FNA dramatically reduced unnecessary diagnostic thyroid surgery by rendering an actionable ROM when the cytological diagnosis was benign, suspicious for malignancy, or malignant. Among patients with cytologically benign lesions the ROM is low, and this combined with the generally indolent nature of thyroid cancer has led clinicians to follow these patients conservatively and avoid diagnostic surgery. In the minority of the patients where FNA cytology is indeterminate, most patients have been referred for diagnostic surgery given the higher ROM (3). The application of molecular diagnostics to these cytologically indeterminate samples offers the opportunity improve patient care by clarifying this diagnostic ambiguity. Immunohistochemistry, microRNA, DNA mutation/ rearrangement testing, and RNA gene expression classification have attempted to end the diagnostic odyssey of these patients. Immunohistochemical and mutational approaches have inadequate sensitivity and NPV for malignancy, such that diagnostic surgery cannot be avoided (3). When a mutation/rearrangement is present, however, the high positive predictive value for malignancy can "rule-in" malignancy and alter patient management by commanding an initial total thyroidectomy as opposed to a diagnostic hemithyroidectomy (34). Currently, the most validated and effective approach to "rule-out" cancer and avoid diagnostic surgery in patients with indeterminate cytology is the Afirma GEC based on its high NPV (34). Opportunities clear exist in the literature and Guidelines to clarify these concepts of "rule-in" versus "rule-out" tests, when they should be used, and which tests meet these definitions. The Afirma GEC is a thyroid genomic test validated in a robust study design via two multicenter, prospective studies against blinded expert histopathology (34). This RNA expression approach reclassifies to benign about one-half of the histologically benign patients with cytologically indetermi- 
nate nodules. This increases the diagnostic specificity of indeterminate cytology from $0 \%$ to $52 \%$. Thus, about half of those with truly benign lesions can be removed from the surgical pool and conservatively followed as if they were cytologically benign. The remaining GEC "suspicious" patients are enriched for malignancy with a positive predictive value of about $40 \%$. Given this intermediate ROM other factors are needed to decide if these patients should undergo a diagnostic hemithyroidectomy or total thyroidectomy. The low frequency of BRAF, RET/PTC, PPARG mutations in AUS/FLUS and FN/SFN patients suggests that testing for these mutations/rearrangements to make this decision may be of low yield $(37,38)$, although testing for RAS mutations may be the most productive $(34,38)$, especially if one found it acceptable to perform a total thyroidectomy in the setting of a benign follicular adenoma with a $R A S$ mutation $(3,38)$. Analytic validity and clinical utility studies, as well as prospective multicenter clinical validation of this gene mutation testing paradigm against blinded histopathology experts remain to be performed.

Disclosure: RTK is a stockholder and employee of Veracyte, Inc. LSW has no conflict of interest.

\section{REFERENCES}

1. Cooper DS, Doherty GM, Haugen BR, Kloos RT, Lee SL, Mandel SJ, et al. Revised American Thyroid Association management guidelines for patients with thyroid nodules and differentiated thyroid cancer. Thyroid. 2009;19(11):1167-214.

2. Hegedus L. Clinical practice. The thyroid nodule. $\mathrm{N}$ Engl J Med. 2004;351(17):1764-71.

3. Melillo RM, Santoro M. Molecular biomarkers in thyroid FNA samples. J Clin Endocrinol Metab. 2012;97(12):4370-3.

4. Wang CC, Friedman L, Kennedy GC, Wang H, Kebebew E, Steward $\mathrm{DL}$, et al. A large multicenter correlation study of thyroid nodule cytopathology and histopathology. Thyroid. 2011;21(3):243-51.

5. Bryson PC, Shores CG, Hart C, Thorne L, Patel MR, Richey L, et al. Immunohistochemical distinction of follicular thyroid adenomas and follicular carcinomas. Arch Otolaryngol Head Neck Surg. 2008;134(6):581-6.

6. Saravanan P, Chau WF, Roberts N, Vedhara K, Greenwood R, Dayan CM. Psychological well-being in patients on "adequate" doses of I-thyroxine: results of a large, controlled community-based questionnaire study. Clin Endocrinol (Oxf). 2002;57(5):577-85.

7. Cooper DS, Biondi B. Subclinical thyroid disease. Lancet. 2012;379(9821):1142-54.

8. Shrime MG, Goldstein DP, Seaberg RM, Sawka AM, Rotstein L, Freeman $\mathrm{JL}$, et al. Cost-effective management of low-risk papillary thyroid carcinoma. Arch Otolaryngol Head Neck Surg. 2007;133(12):1245-53.

9. Esnaola NF, Cantor SB, Sherman SI, Lee JE, Evans DB. Optimal treatment strategy in patients with papillary thyroid cancer: a decision analysis. Surgery. 2001;130(6):921-30.
10. Hundahl SA, Cady B, Cunningham MP, Mazzaferri E, McKee RF, Rosai J, et al. Initial results from a prospective cohort study of 5,583 cases of thyroid carcinoma treated in the United States during 1996. U.S. and German Thyroid Cancer Study Group. An American College of Surgeons Commission on Cancer Patient Care Evaluation study. Cancer. 2000;89(1):202-17.

11. Bergenfelz A, Jansson S, Kristoffersson A, Martensson H, Reihner E, Wallin $G$, et al. Complications to thyroid surgery: results as reported in a database from a multicenter audit comprising 3,660 patients. Langenbecks Arch Surg. 2008;393(5):667-73.

12. Ernandes-Neto M, Tagliarini JV, Lopez BE, Padovani CR, Marques Mde A, Castilho EC, et al. Factors influencing thyroidectomy complications. Braz J Otorhinolaryngol. 2012;78(3):63-9.

13. Sosa JA, Bowman HM, Tielsch JM, Powe NR, Gordon TA, Udelsman R. The importance of surgeon experience for clinical and economic outcomes from thyroidectomy. Ann Surg. 1998;228(3):320-30.

14. Saunders BD, Wainess RM, Dimick JB, Doherty GM, Upchurch GR, Gauger PG. Who performs endocrine operations in the United States? Surgery. 2003;134(6):924-931; discussion 931.

15. Gonzalez-Sanchez C, Franch-Arcas G, Gomez-Alonso A. Morbidity following thyroid surgery: does surgeon volume matter? Langenbecks Arch Surg. 2012 Nov 6.

16. Borget I, Vielh P, Leboulleux S, Allyn M, lacobelli S, Schlumberger $M$, et al. Assessment of the cost of fine-needle aspiration cytology as a diagnostic tool in patients with thyroid nodules. Am J Clin Pathol. 2008;129(5):763-71.

17. Renshaw A. An estimate of risk of malignancy for a benign diagnosis in thyroid fine-needle aspirates. Cancer Cytopathol. 2010;118(4):190-5.

18. Lewis CM, Chang KP, Pitman M, Faquin WC, Randolph GW. Thyroid fine-needle aspiration biopsy: variability in reporting. Thyroid. 2009;19(7):717-23.

19. Shrestha M, Crothers BA, Burch HB. The impact of thyroid nodule size on the risk of malignancy and accuracy of fine-needle aspiration: a 10-year study from a single institution. Thyroid. 2012;22(12):1251-6.

20. Alexander EK, Kennedy GC, Baloch ZW, Cibas ES, Chudova D, Diggans $\mathrm{J}$, et al. Preoperative diagnosis of benign thyroid nodules with indeterminate cytology. N Engl J Med. 2012;367:705-15.

21. Marchevsky AM, Walts AE, Bose S, Gupta R, Fan X, Frishberg D, et al. Evidence-based evaluation of the risks of malignancy predicted by thyroid fine-needle aspiration biopsies. Diagn Cytopathol. 2010;38(4):252-9.

22. Davies L, Welch HG. Thyroid cancer survival in the United States: observational data from 1973 to 2005. Arch Otolaryngol Head Neck Surg. 2010;136(5):440-4.

23. Ito $Y$, Miyauchi $A$, Inoue $H$, Fukushima M, Kihara M, Higashiyama $T$, et al. An observational trial for papillary thyroid microcarcinoma in Japanese patients. World J Surg. 2010;34(1):28-35.

24. Renshaw AA. Subclassification of atypical cells of undetermined significance in direct smears of fine-needle aspirations of the thyroid: distinct patterns and associated risk of malignancy. Cancer Cytopathol. 2011;119(5):322-7.

25. Piana S, Frasoldati A, Ferrari M, Valcavi R, Froio E, Barbieri V, et al. Is a five-category reporting scheme for thyroid fine needle aspiration cytology accurate? Experience of over 18,000 FNAs reported at the same institution during 1998-2007. Cytopathology. 2011;22(3):164-73.

26. Cibas ES, Ali SZ. The Bethesda System for Reporting Thyroid Cytopathology. Thyroid. 2009;19(11):1159-65.

27. Walts AE, Bose S, Fan X, Frishberg D, Scharre K, de Peralta-Venturina $M$, et al. A simplified Bethesda System for reporting thyroid cytopathology using only four categories improves intra- and in- 
ter-observer diagnostic agreement and provides non-overlapping estimates of malignancy risks. Diagn Cytopathol. 2012;40 Suppl 1:E62-8.

28. VanderLaan PA, Marqusee E, Krane JF. Clinical outcome for atypia of undetermined significance in thyroid fine-needle aspirations: should repeated fna be the preferred initial approach? Am J Clin Pathol. 2011;135(5):770-5.

29. Bongiovanni M, Krane JF, Cibas ES, Faquin WC. The atypical thyroid fine-needle aspiration: past, present, and future. Cancer $\mathrm{Cy}$ topathol. 2012;120(2):73-86.

30. Faquin WC, Baloch ZW. Fine-needle aspiration of follicular patterned lesions of the thyroid: diagnosis, management, and follow-up according to National Cancer Institute $(\mathrm{NCl})$ recommendations. Diagn Cytopathol. 2010;38(10):731-9.

31. Renshaw AA. Does a repeated benign aspirate change the risk of malignancy after an initial atypical thyroid fine-needle aspiration? Am J Clin Pathol. 2010;134(5):788-92.

32. Na DG, Kim JH, Sung JY, Baek JH, Jung KC, Lee H, et al. Coreneedle biopsy is more useful than repeat fine-needle aspiration in thyroid nodules read as nondiagnostic or atypia of undetermined significance by the Bethesda system for reporting thyroid cytopathology. Thyroid. 2012;22(5):468-75.

33. de Matos PS, Ferreira AP, de Oliveira Facuri F, Assumpcao LV, Metze K, Ward LS. Usefulness of HBME-1, cytokeratin 19 and galectin-3 immunostaining in the diagnosis of thyroid malignancy. Histopathology. 2005;47(4):391-401.

34. Kim Ml, Alexander EK. Diagnostic use of molecular markers in the evaluation of thyroid nodules. Endocr Pract. 2012;18(5):796-802.

35. Lodewijk L, Prins AM, Kist JW, Valk GD, Kranenburg O, Rinkes IH, et al. The value of miRNA in diagnosing thyroid cancer: a systematic review. Cancer Biomark. 2012;11(6):229-38.

36. Dettmer M, Vogetseder A, Durso MB, Moch H, Komminoth P, Perren $A$, et al. MicroRNA expression array identifies novel diagnostic markers for conventional and oncocytic follicular thyroid carcinomas. J Clin Endocrinol Metab. 2013;98(1):E1-7.

37. Kleiman DA, Sporn MJ, Beninato T, Crowley MJ, Nguyen A, Uccelli $A$, et al. Preoperative BRAF(V600E) mutation screening is unlikely to alter initial surgical treatment of patients with indeterminate thyroid nodules: a prospective case series of 960 patients. Cancer. 2012 Dec 21.

38. Nikiforov YE, Ohori NP, Hodak SP, Carty SE, LeBeau SO, Ferris RL, et al. Impact of mutational testing on the diagnosis and management of patients with cytologically indeterminate thyroid nodules: a prospective analysis of 1056 FNA samples. J Clin Endocrinol Metab. 2011;96(11):3390-7.

39. Ferraz C, Eszlinger M, Paschke R. Current state and future perspective of molecular diagnosis of fine-needle aspiration biopsy of thyroid nodules. J Clin Endocrinol Metab. 2011;96(7):2016-26.

40. Yip L, Farris C, Kabaker AS, Hodak SP, Nikiforova MN, McCoy KL, et al. Cost impact of molecular testing for indeterminate thyroid nodule fine-needle aspiration biopsies. J Clin Endocrinol Metab. 2012;97(6):1905-12.

41. Jameson JL. Minimizing unnecessary surgery for thyroid nodules. N Engl J Med. 2012;367(8):765-7.

42. NCCN Clinical Practice Guidelines in Oncology. Thyroid Carcinoma. Available: http://www.nccn.org/professionals/physician_gls/ pdf/thyroid.pdf. Accessed on: Jan 9, 2013.

43. Walsh PS, Wilde JI, Tom EY, Reynolds JD, Chen DC, Chudova DI, et al. Analytical performance verification of a molecular diagnostic for cytology-indeterminate thyroid nodules. J Clin Endocrinol Metab. 2012;97(12):E2297-306.

44. Chudova D, Wilde JI, Wang ET, Wang H, Rabbee N, Egidio $\mathrm{CM}$, et al. Molecular classification of thyroid nodules using high-dimensionality genomic data. J Clin Endocrinol Metab. 2010;95(12):5296-304.
45. Lew JI, Snyder RA, Sanchez YM, Solorzano CC. Fine needle aspiration of the thyroid: correlation with final histopathology in a surgical series of 797 patients. J Am Coll Surg. 2011;213(1):188194; discussion 194-85.

46. Papaparaskeva K, Nagel H, Droese M. Cytologic diagnosis of medullary carcinoma of the thyroid gland. Diagn Cytopathol. 2000;22(6):351-8.

47. Shah SS, Faquin WC, Izquierdo R, Khurana KK. FNA of misclassified primary malignant neoplasms of the thyroid: impact on clinical management. Cytojournal. 2009;6:1.

48. Jo VY, Stelow EB, Dustin SM, Hanley KZ. Malignancy risk for fineneedle aspiration of thyroid lesions according to the Bethesda System for Reporting Thyroid Cytopathology. Am J Clin Pathol. 2010;134(3):450-6.

49. Choi N, Moon WJ, Lee JH, Baek JH, Kim DW, Park SW. Ultrasonographic findings of medullary thyroid cancer: differences according to tumor size and correlation with fine needle aspiration results. Acta Radiol. 2011;52(3):312-6.

50. Bugalho MJ, Santos JR, Sobrinho L. Preoperative diagnosis of medullary thyroid carcinoma: fine needle aspiration cytology as compared with serum calcitonin measurement. J Surg Oncol. 2005;91(1):56-60.

51. Kudo T, Miyauchi A, Ito Y, Takamura Y, Amino N, Hirokawa M. Diagnosis of medullary thyroid carcinoma by calcitonin measurement in fine-needle aspiration biopsy specimens. Thyroid. 2007;17(7):635-8.

52. Dustin SM, Jo VY, Hanley KZ, Stelow EB. High sensitivity and positive predictive value of fine-needle aspiration for uncommon thyroid malignancies. Diagn Cytopathol. 2012;40(5):416-21.

53. Elisei R, Bottici V, Luchetti F, Di Coscio G, Romei C, Grasso L, et al. Impact of routine measurement of serum calcitonin on the diagnosis and outcome of medullary thyroid cancer: experience in 10,864 patients with nodular thyroid disorders. J Clin Endocrinol Metab. 2004;89(1):163-8.

54. Fischer AH, Clayton AC, Bentz JS, Wasserman PG, Henry MR, Souers RJ, et al. Performance differences between conventional smears and liquid-based preparations of thyroid fineneedle aspiration samples: analysis of 47,076 responses in the College of American Pathologists Interlaboratory Comparison Program in Non-Gynecologic Cytology. Arch Pathol Lab Med. 2013;137(1):26-31.

55. Kloos RT, O'Reilly K, Traweek ST, Alexander EK, Harrell RM, Haugen BR, et al. Novel gene expression classifier raises pre-operative suspicion of medullary thyroid cancer (abstract). AACE 21st Annual Scientific and Clinical Congress. Philadelphia, PA; 2012.

56. Costante G, Durante C, Francis Z, Schlumberger M, Filetti S. Determination of calcitonin levels in C-cell disease: clinical interest and potential pitfalls. Nat Clin Pract Endocrinol Metab. 2009;5(1):35-44

57. Kloos RT, Eng C, Evans DB, Francis GL, Gagel RF, Gharib H, et al. Medullary thyroid cancer: management guidelines of the American Thyroid Association. Thyroid. 2009;19(6):565-612.

58. Duick DS, Klopper JP, Diggans JC, Friedman L, Kennedy GC, Lanman RB, et al. The Impact of Benign Gene Expression Classifier Test Results on the Endocrinologist-Patient Decision to Operate on Patients with Thyroid Nodules with Indeterminate Fine-Needle Aspiration Cytopathology. Thyroid. 2012 Jul 11.

59. Li H, Robinson KA, Anton B, Saldanha IJ, Ladenson PW. Cost-effectiveness of a novel molecular test for cytologically indeterminate thyroid nodules. J Clin Endocrinol Metab. 2011;96(11):E171926.

60. Yassa L, Cibas ES, Benson CB, Frates MC, Doubilet PM, Gawande $A A$, et al. Long-term assessment of a multidisciplinary approach to thyroid nodule diagnostic evaluation. Cancer. 2007;111(6):508-16. 
errata

\section{Correção do Artigo}

\section{Molecular markers in the diagnosis of thyroid nodules}

Laura S. Ward, Richard T. Kloos

Arq Bras Endocrinol Metab. 2013;57(2):89-97

Na Figure 3, onde se lê:

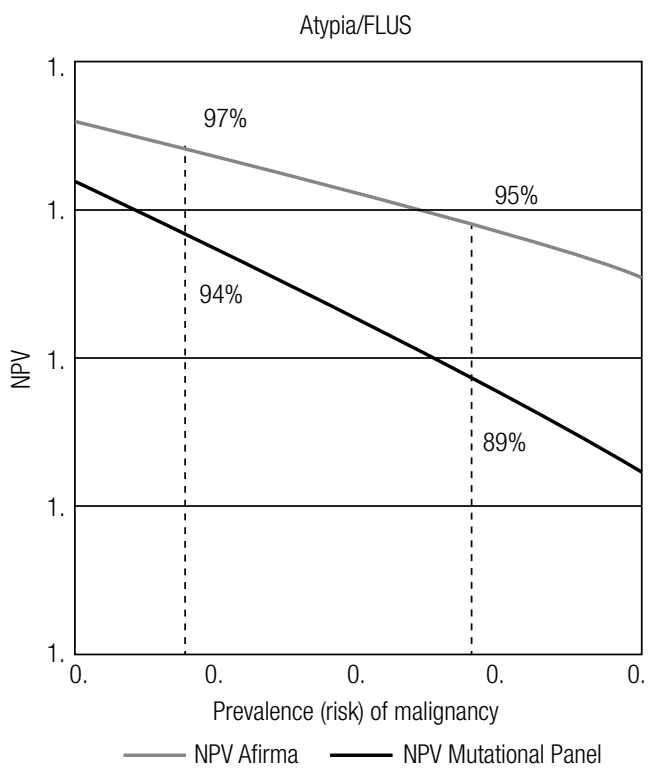

Figure 3. Negative predictive value (NPV) of Afirma (20) and a Mutational Panel (38) according to the prevalence of malignancy.
Leia-se:

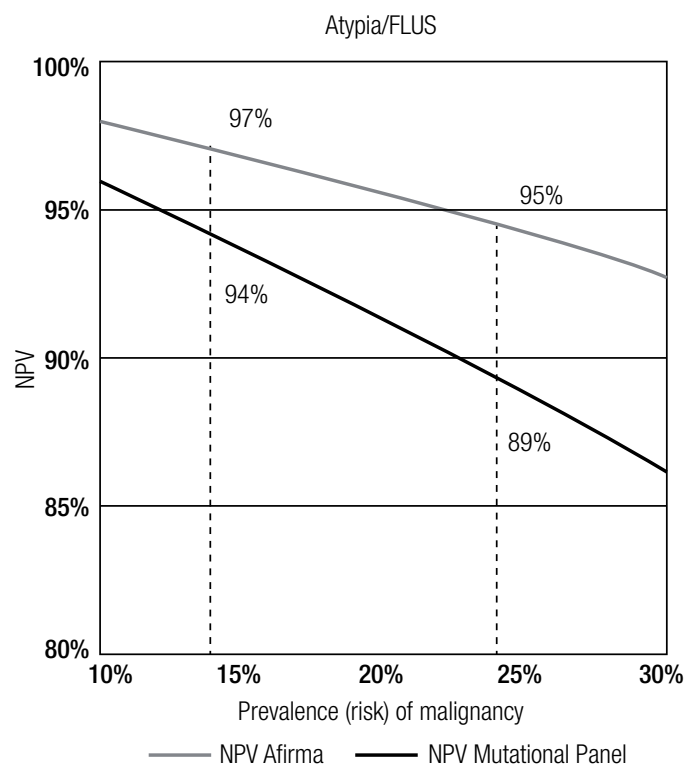

Figure 3. Negative predictive value (NPV) of Afirma (20) and a Mutational Panel (38) according to the prevalence of malignancy. 